\title{
The camelliagenin from defatted seeds of Camellia oleifera as antibiotic substitute to treat chicken against infection of Escherichia coli and Staphylococcus aureus
}

\author{
Yong Ye*, Qian Yang, Fei Fang and Yue Li
}

\begin{abstract}
Background: Escherichia coli and Staphylococcus aureus are the main pathogens infectious to poultry, and their resistances against antibiotics have become troublesome currently. Biofilm formation is an important reason for drug resistance. Our previous research has found that the extract of Camellia oleifera seeds has lots of pharmacological effects. In order to find the substitute for antibiotics, the saponin was isolated from the defatted $C$. oleifera seeds with structural identification. Its efficacy was evaluated by the inhibition on amoxicillin-resistant E. coli and erythromycin-resistant $S$. aureus and therapeutic effect on chicks infected by the two bacteria.

Results: The bacterial growth inhibition rate increased and the bacterial count in vivo decreased significantly in dose dependence after administration of the saponin and its combination with amoxicillin or erythromycin, suggesting its antibacterial effect. The saponin identified as camelliagenin shows significant inhibition on the biofilm of E. coli and S. aureus, and it is related to the decrease of mannitol dehydrogenase (MDH) activity and extracellular DNA (eDNA) content. Molecular simulation reveals the strong interaction existing between the saponin and $\mathrm{MDH}$ or eDNA.

Conclusions: The mechanism of camelliagenin's improvement on antibiotic effects is its interaction with MDH and eDNA in biofilm. The saponin is a prospective substitute of antibiotics, and molecular simulation is a convenient alternative method to find out hopeful candidates of antibiotics substitute.
\end{abstract}

Keywords: Camellia oleifera, Camelliagenin, Antibacterial effect, Bacterial biofilm, Antibiotic substitute

\section{Background}

Escherichia coli and Staphylococcus aureus are major pathogenic bacteria infectious to poultry. E. coli causes the colibacillosis such as acute septicaemia, vitelline peritonitis, enteritis, genital diseases, and so forth, its morbidity and lethality are the highest in bacterial diseases of chicks in China $[1,2]$. The pathogen is currently treated by antibiotics, but its resistance against antibiotics can be easily acquired, and antibiotics lead to the deficiency of therapeutic effects [3]. S. aureus can cause acute septicaemia, arthritis, chick omphalitis,

\footnotetext{
* Correspondence: yeyong@scut.edu.cn
Department of Pharmaceutical Engineering, School of Chemistry and

* Correspondence: yeyong@scut.edu.cn Chemical Engineering, South China University of Technology, Guangzhou 510640, P R China
}

cutaneous necrosis and periostitis, and it is another pathogen leading great economic losses to the animal husbandry in China [4]. It is also easy to acquire drug resistance; especially methicillin resistant S. aureus (MRSA) is resistant to most of antibiotics. The resistance against antibiotics becomes great threat to animals and human being, and it is meaningful to find out the antibiotic substitute to reduce the usage of antibiotics. Herbs and plants offer plenty of compounds, which may Cace antibiotics with strong antibacterial activities.

Camellia oleifera, an evergreen plant, mainly grows in the middle region of China. Its seeds are used for the extraction of edible oil. The yield of the seeds dramatically increases in recent years because of plant edible oil requirement and cultivation, the production of defatted 
seeds is up to 800,000 tons per year [5]. Although the defatted seeds are rich in active compounds [6,7], they have been discarded without isolation and further exploitation. The total flavonoids, saponins and polysaccharides were detected in seeds of Camellia oleifera with the contents of $1-3,10-14$ and $15-20 \%$ respectively [8-10]. The effective utilization of them will provide large amount of bioactive products. It is valuable to extract them for industrialization.

Our previous research has found that the extract of Camellia oleifera seeds have lots of pharmacological effects such as antioxidation, anti-inflammation and analgesia, which are mainly due to the saponin [11]. It is possible to develop the saponin extract as antibiotic substitute for animal husbandry because of its abundant and cheap resource.

In order to evaluate its effect and discuss the mechanism, the saponin was isolated from the defatted seeds of $C$. oleifera with structural identification. Its efficacy was evaluated by amoxicillin-resistant E. coli and erythromycinresistant $S$. aureus induced infection in chicks. Bacterial biofilm formation is an important reason for the resistance against antibiotics, recurrence and difficulty to control by chemicals [12]. The action mechanism was revealed by inhibitory effect of the saponin on biofilm formation through interaction with mannitol dehydrogenase (MDH) activity and extracellular DNA (eDNA).

\section{Results and discussion}

Purity of the extract and structure of the purified compound Natural saponins generally exist in forms of glycosides, and different kinds of glycosides of saponin have been found in seeds of C. oleifera [13]. Saponin glycosides are soluble in water and aqueous solvents. The extracts are the mixture of different glycosides, which can be achieved by current technique [14]. $\mathrm{HCl}$ aqueous solution with ultrasonic extraction applied in our research can hydrolyze saponin glycosides into sapogenin, which are insoluble in water and easily isolated by precipitation to get the purified products.

Average yield of the saponin extract was (12.5 \pm 0.7$) \%$ by the separation technique in three repetitions. Purity of the extract was calculated by peak areas in HPLC (Fig. 1). Relative percentage of saponin is $(82.3 \pm 4.2) \%$. The yield and purity suggests that the technique is practical and cost effective because the ultrasonic assisted acid-base alternative extraction does not need organic solvent and expensive equipment. Ultrasonic can expedite dissolution in lower temperature, which protects activity of thermosensitive compounds in the extraction [15].

The purified saponin was amorphous powder, insoluble in water, and soluble in ethanol, acetone and DMSO. mp 251.2-251.7 ${ }^{\circ} \mathrm{C}, \mathrm{m} / \mathrm{z} 488.1(\mathrm{M}+)$. There was an absorption peak of UV at $207 \mathrm{~nm}$. IR spectra: hydroxyl $\left(3435 \mathrm{~cm}^{-1}\right)$, no characteristic absorption of $\alpha, \beta$-unsaturated ester and ether. There were one carbonyl ( $\mathrm{d} 9.49, \mathrm{~J}=12.48$ ), two olefinic protons (d 8.01, 7.49) but no Tig moiety signal in ${ }^{1} \mathrm{H}$ NMR spectra. The signals of ${ }^{13} \mathrm{C}$ NMR spectra were shown in Fig. 2 and attributable to the following: $\delta 206.5$ (C-25), 143.5 (C-12), 121.6 (C-13), 76.7 (C-19), 74.1 (C-2), 69.7 (C-31), 66.8 (C-16), 57.4 (C-3), 47.5 (C-4, 10, 22), 44.7 (C-17), 42.6 (C-11, 20), 40.3 (C-9, 18), 37.9 (C-5, 6, 15), 31.7 (C-8, 20), 28.4 (C-28, 29), 24.2 (C-14, 34), 15.3 $(\mathrm{C}-24,26,27)$. It is a sapogenin structure named camelliagenin $\left(\mathrm{C}_{30} \mathrm{H}_{48} \mathrm{O}_{5}\right)$, which is consistent with literature [16]. Its structure is shown in Fig. 3.

\section{Inhibitory effect of the saponin on bacteria in vitro and in vivo}

Inhibitory effect of the saponin on bacteria in vitro was measured by $\mathrm{MIC}_{90}$ and $\mathrm{IC}_{50}$ of the camelliagenin on bacterial growth in culture medium. $\mathrm{MIC}_{90}$ of the saponin on 35 strains of $E$. coli and 30 strains of $S$. aureus was separately $71.4 \pm 6.3 \mu \mathrm{g} / \mathrm{ml}$ and $94.5 \pm 9.7 \mu \mathrm{g} / \mathrm{ml}$. The camelliagenin had significant inhibition on growth of both $E$. coli and $S$. aureus, but its effect on $E$. coli was stronger than $S$. aureus suggestive of its selectivity. Amoxicillin and erythromycin had no obvious inhibitory effects on the two bacteria, indicating that the bacteria were resistant against the antibiotics. The camelliagenin plus antibiotics had better inhibition on bacteria than the camelliagenin or antibiotics alone, showing that the camelliagenin can strengthen bacterial sensitivity to antibiotics (Table 1).

Inhibition of the camelliagenin on bacteria in vivo was evaluated by its therapeutic effect on chicks induced by E. coli and S. aureus. Chicks in negative groups showed serious symptoms of depression, anorexia, dullness, and diarrhea. Amoxicillin and erythromycin did not relieve these symptoms obviously, suggesting bacterial resistance against the antibiotics. The camelliagenin and combined administration of the camelliagenin and antibiotics significantly $(p<0.01)$ increased the body weight, immune organ index and reduced bacterial counts of liver in dose dependence, indicating that the camelliagenin enhances bacterial sensitivity to antibiotics and improves chicks immunity. The results are shown in Fig. 4. It further proves that the camelliagenin can not only substitute antibiotics, but also enhance antibiotic effects.

In order to reduce the number of experimental animals and limitation of models, inhibitory tests were both carried out on bacteria in vitro and in vivo. The results show positive effects on inhibition of bacterial growth, indicating that the camelliagenin is promising as an effective antibacterial agent for $E$. coli and $S$. aureus. It may take effects on other kinds of bacteria, but needs further evaluation.

\section{Effects of the camelliagenin on biofilm formation and exudates}

Bacterial biofilm is a key factor to induce resistance against antibiotics and a target of new antimicrobials 


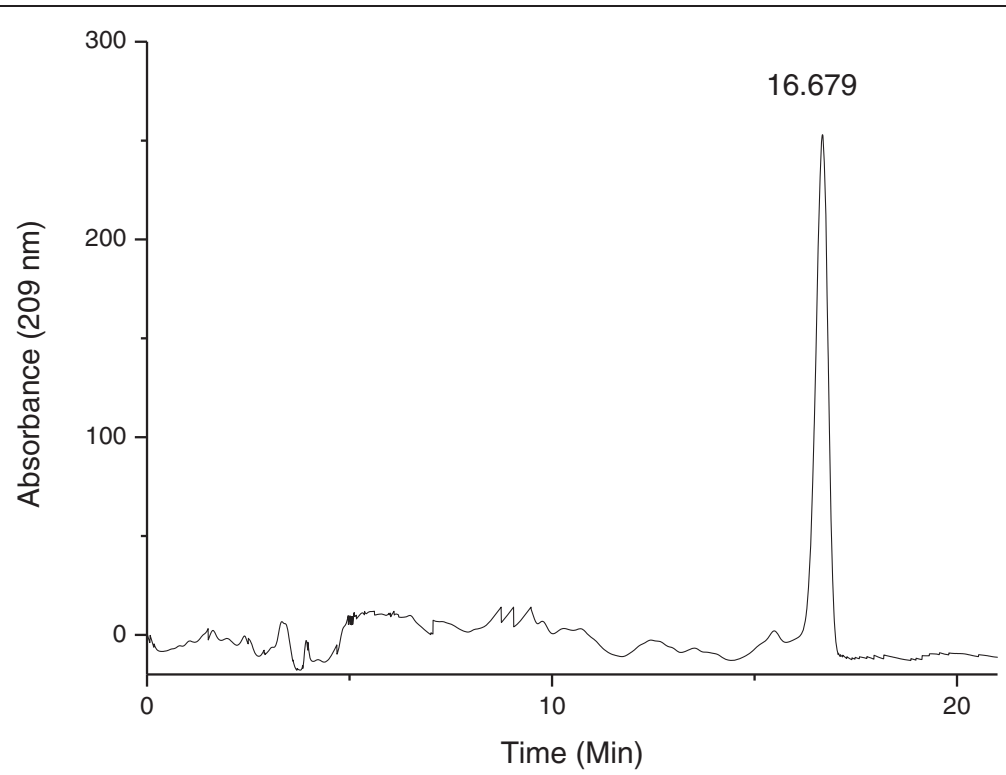

Fig. 1 HPLC chromatograph of the saponin extract



Fig. 2 NMR spectra of the camelliagenin 


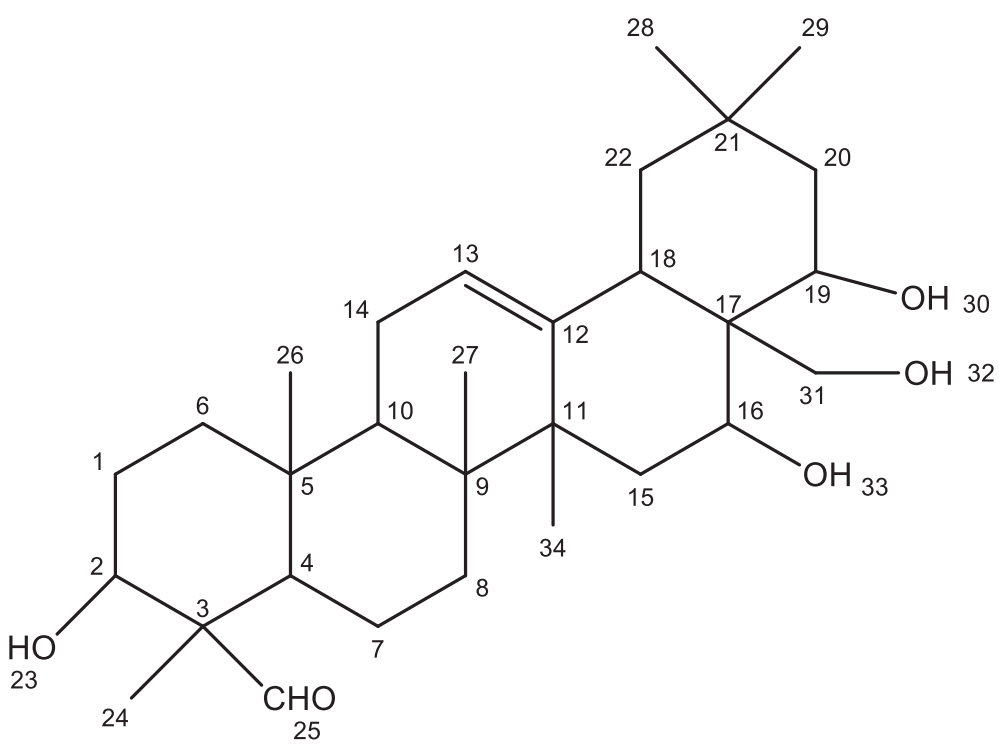

Fig. 3 Structures of the saponin isolated from the defatted seeds of Camellia oleifera

[17]. Thus the biofilms of E. coli and S. aureus were analyzed in our research. The results showed that amoxicillin or erythromycin had no different effect on biofilms from negative group (Table 1 ), and $\mathrm{IC}_{50}$ of the camelliagenin on biofilm of the two bacteria were lower than that of amoxicillin or erythromycin at significant level $(p<0.01)$. It indicates that antibacterial effects of the camelliagenin are related to its inhibition on bacterial biofilm formation.

The expression of specific genes is involved in biofilm formation and responsible for bacterial drug resistance [18]. The main difference between biofilm bacteria and planktonic bacteria is that biofilm bacteria are tightly

Table 1 Inhibition concentration $(\mu \mathrm{g} / \mathrm{ml})$ of the saponin extract on $50 \%$ bacterial growth and biofilm formation of Escherichia coli and Staphylococcus aureus

\begin{tabular}{llllll}
\hline Groups & \multicolumn{3}{l}{ E. coli } & \multicolumn{3}{l}{ S. aureus } \\
\cline { 2 - 3 } \cline { 6 - 6 } & Growth & Biofilm & & Growth & \multicolumn{1}{l}{ Biofilm } \\
\hline Amo & $72.6 \pm 7.9$ & $72.8 \pm 9.6$ & & $138.6 \pm 11.0$ & $129.8 \pm 10.5$ \\
Sap & $50.2 \pm 5.7^{\mathrm{a}}$ & $43.6 \pm 4.2^{\mathrm{a}}$ & $79.6 \pm 9.1^{\mathrm{a}}$ & $70.2 \pm 10.2^{\mathrm{a}}$ \\
Sap : Amo (1:1) & $30.4 \pm 6.5^{\mathrm{a}, \mathrm{b}}$ & $22.8 \pm 5.2^{\mathrm{a}, \mathrm{b}}$ & $59.0 \pm 9.6^{\mathrm{a}, \mathrm{b}}$ & $52.4 \pm 8.0^{\mathrm{a}, \mathrm{b}}$ \\
Sap : Amo (5:1) & $23.4 \pm 5.6^{\mathrm{a}, \mathrm{b}}$ & $18.6 \pm 5.7^{\mathrm{a}, \mathrm{b}}$ & $43.2 \pm 5.9^{\mathrm{a}, \mathrm{b}}$ & $39.2 \pm 3.5^{\mathrm{a}, \mathrm{b}}$ \\
Sap : Amo (10:1) & $21.6 \pm 5.1^{\mathrm{a}, \mathrm{b}}$ & $15.6 \pm 3.5^{\mathrm{a}, \mathrm{b}}$ & & $35.2 \pm 4.5^{\mathrm{a}, \mathrm{b}}$ & $30.2 \pm 7.0^{\mathrm{a}, \mathrm{b}}$ \\
Ery & $69.2 \pm 6.3$ & $65.6 \pm 10.5$ & & $126.2 \pm 6.7$ & $122.8 \pm 8.3$ \\
Sap : Ery (1:1) & $28.2 \pm 5.2^{\mathrm{b}, \mathrm{c}}$ & $26.8 \pm 6.8^{\mathrm{b}, \mathrm{c}}$ & $51.6 \pm 8.0^{\mathrm{b}, \mathrm{c}}$ & $44.4 \pm 6.1^{\mathrm{b}, \mathrm{c}}$ \\
Sap : Ery (5:1) & $24.4 \pm 4.7^{\mathrm{b}, \mathrm{c}}$ & $19.2 \pm 4.8^{\mathrm{b}, \mathrm{c}}$ & & $35.4 \pm 5.3^{\mathrm{b}, \mathrm{c}}$ & $28.6 \pm 6.3^{\mathrm{b}, \mathrm{c}}$ \\
Sap : Ery (10:1) & $13.4 \pm 3.9^{\mathrm{b}, \mathrm{c}}$ & $12.8 \pm 5.1^{\mathrm{b}, \mathrm{c}}$ & $27.6 \pm 5.7^{\mathrm{b}, \mathrm{c}}$ & $22.8 \pm 6.2^{\mathrm{b}, \mathrm{c}}$ \\
\hline
\end{tabular}

Data were presented as mean \pm standard deviation $(n=5)$

Amo amoxicillin, Sap saponin, Ery erythromycin

${ }^{a} p<0.01$, compared with amoxicillin

${ }^{\mathrm{b}} p<0.01$, compared with the saponin

$c_{p}<0.01$, compared with erythromycin packed and wrapped in their own secreted extracellular polysaccharide matrix called extracellular polymeric substances (EPS). The main component of EPS is alginate [19]. Mannitol dehydrogenase is a key enzyme in alginate synthesis process of biofilm [20]. Some antimicrobials can destroy biofilm formation since it inhibits activity of mannitol dehydrogenase in biosynthetic pathway of alginate [21]. In addition, large amount of extracellular DNA (eDNA) is found in the biofilm [22], it not only affects the formation of biofilms, but also increases the resistance of biofilms by chelating cation [23]. It is proved that eDNA enzymes can clear immature biofilm in vitro [24], and biofilm formation can be regulated by mannitol dehydrogenase and eDNA [25].

$\mathrm{MDH}$ and eDNA in biofilm were measured respectively by a decrease in the absorbance of reactive mixture at $340 \mathrm{~nm}$ and biofilm lysate at $260 \mathrm{~nm}$ compared to untreated controls. $\Delta \mathrm{A}_{340}$ and $\Delta \mathrm{A}_{260}$ increased significantly $(p<0.01)$ after the treatments of the camelliagenin at concentration dependence (Fig. 5). It suggests that they play a role in the inhibition of MDH and eDNA in the biofilms.

\section{Interaction of the camelliagenin with mannitol dehydrogenase and eDNA}

Molecular docking as a better method of molecular simulation is applied in this research. Docking simulation shows that the saponin can interact with mannitol dehydrogenase (MDH) and eDNA. Each molecule successfully docks in 10 poses. The average binding energy is separately $-86.94 \pm 1.99 \mathrm{kcal} / \mathrm{mol}$ and $-105.01 \pm$ $1.19 \mathrm{kcal} / \mathrm{mol}$, the average interactive energy is respectively $39.70 \pm 2.28 \mathrm{kcal} / \mathrm{mol}$ and $19.77 \pm 1.64 \mathrm{kcal} / \mathrm{mol}$. It 


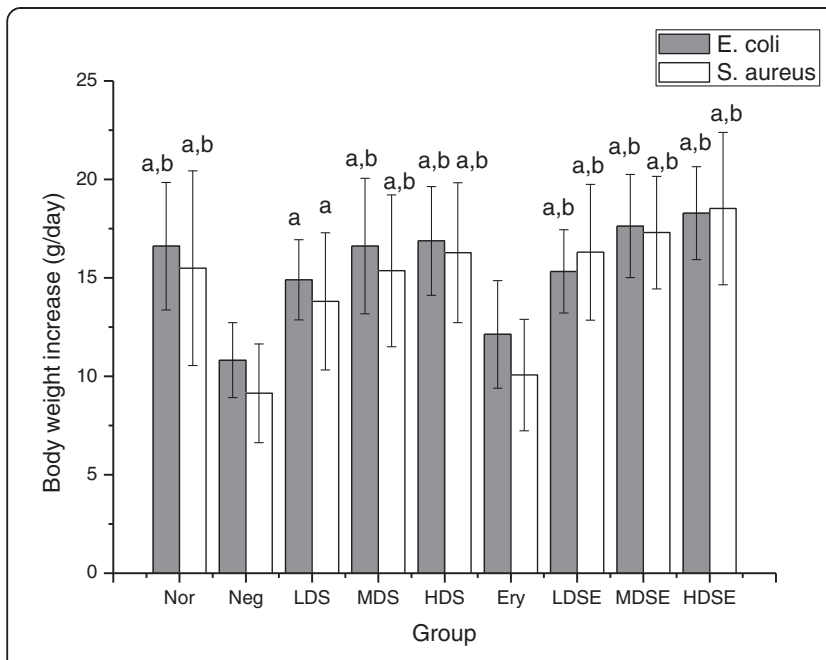

(a)

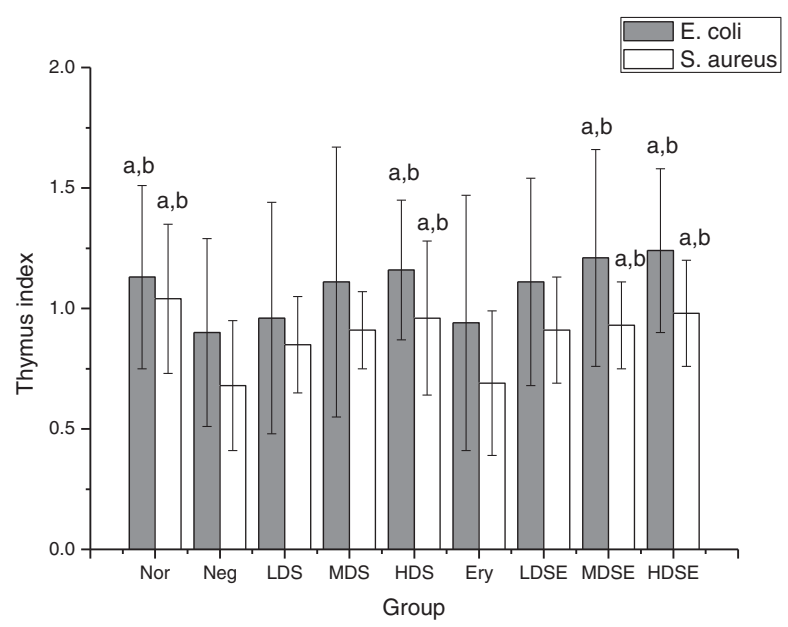

(c)

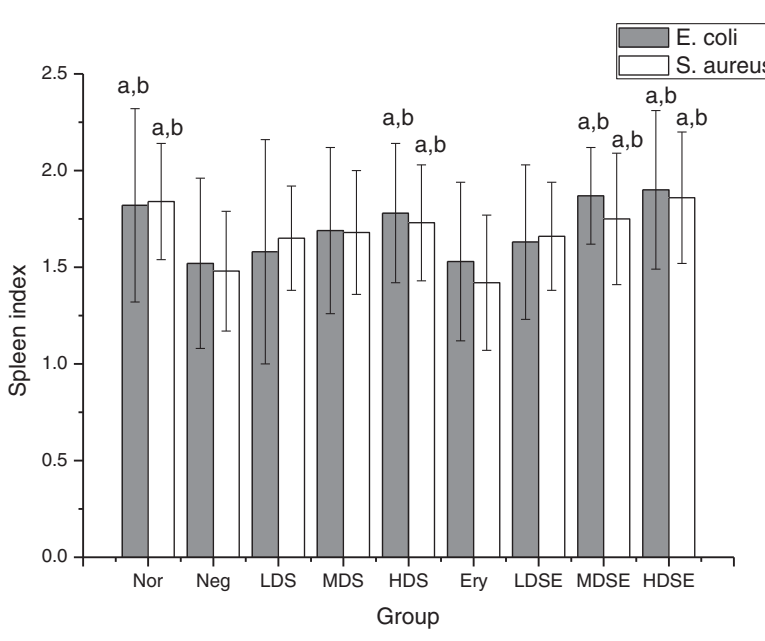

(b)



(d)

Fig. 4 The effects of the saponin on body weight increase (a), spleen index (b), thymus index (c) and bacterial count (d) in liver of chicks infected by Escherichia coli and Staphylococcus aureus. Chicks in each group were injected intraperitoneally by $0.2 \mathrm{ml}\left(1 \times 10^{8}\right.$ CFU/ml) of E. coli or S. aureus suspension except normal group, $10 \mathrm{~h}$ later administered with feed containing erythromycin (50 mg/kg) or the saponin (50 mg/kg in low dose, $250 \mathrm{mg} / \mathrm{kg}$ in middle dose, $500 \mathrm{mg} / \mathrm{kg}$ in high dose) respectively for consecutive $3 \mathrm{~d}$. The chicks were weighed, monitored for $14 \mathrm{~d}$. a, $p<0.01$, compared with negative group; b, $p<0.01$, compared with erythromycin group. Nor: normal group; Neg: negative group; LDS: low dose of the saponin; MDS: middle dose of the saponin; HDS: high dose of the saponin; Ery: erythromycin; LDSE: Iow dose of the saponin + erythromycin; MDSE: middle dose of the saponin + erythromycin; HDSE: high dose of the saponin + erythromycin

suggests that the camelliagenin can spontaneously bind to $\mathrm{MDH}$ and eDNA and exerts stronger interaction. Mimic diagrams of the camelliagenin binding to mannitol dehydrogenase and DNA are shown in Fig. 6, illustrating that they can well bind and interact with each other.

Based on the lock-key principle and complementary structural hypothesis, molecular docking simulates mutual interaction between ligand and receptor [26]. If receptor and ligand can interact, they must approach each other, and then combine in a particular conformation of the binding site, finally reach stable complex by adjusting conformation. Correct affinity prediction is conducive to drug design and screening. The main factors affecting the binding stability of ligand and receptor are hydrophobic force and bonding force. Free energy value is an important parameter for evaluation of docking affinity, binding activity and stability of receptor and ligand, and it can be used to judge the interaction of ligand and receptor. We simulated the interaction of the camelliagenin with mannitol dehydrogenase and eDNA, the result shows a good correlation between the interaction and 

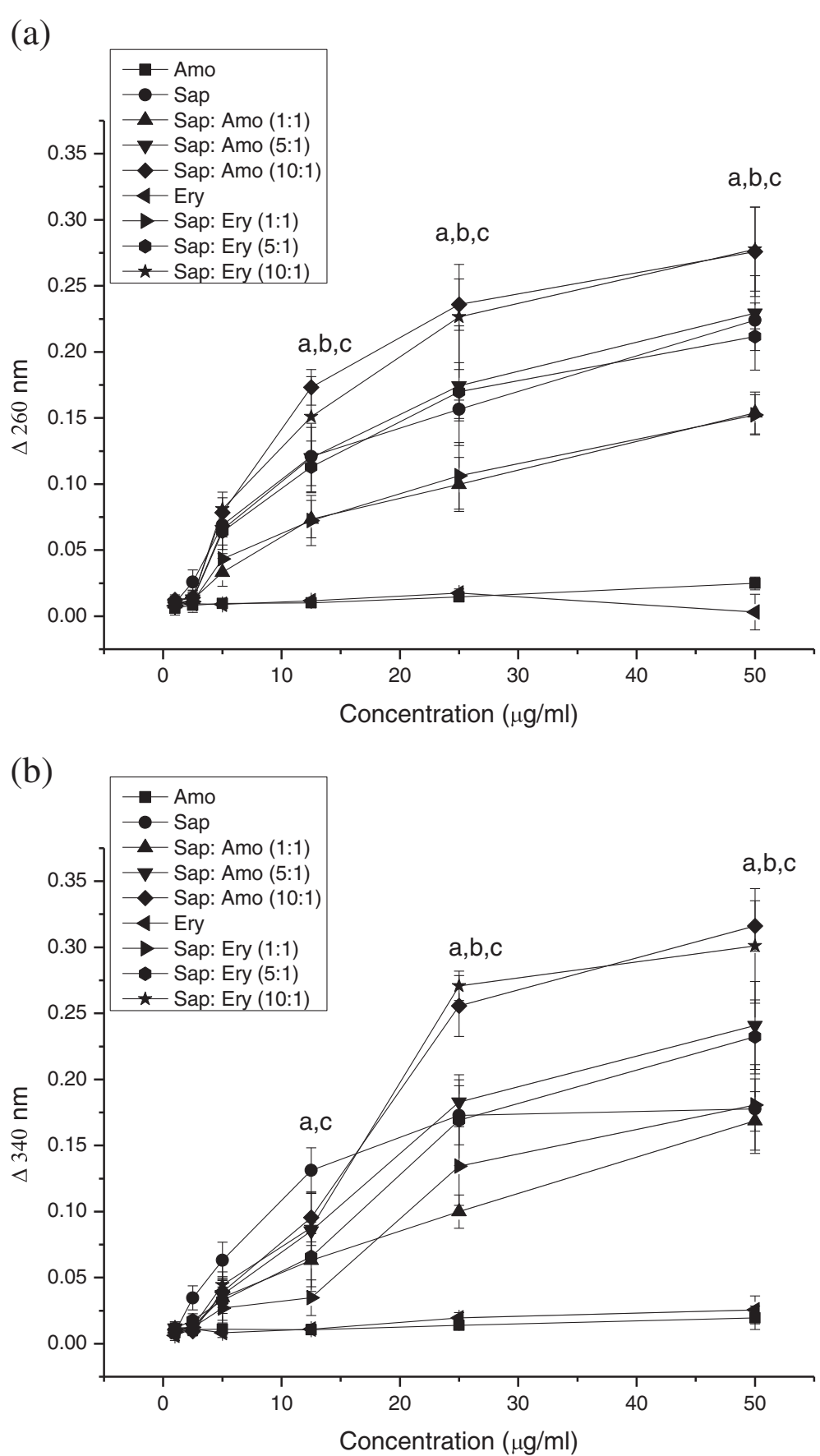

Fig. 5 Activity of mannitol dehydrogenase (a) and content of extracellular DNA (b) in bacterial biofilm affected by the saponin and antibiotics $(\bar{x}+s, n=5)$. Data were measured respectively by a decrease in the absorbance of reactive mixture at $340 \mathrm{~nm}$ and biofilm lysate at $260 \mathrm{~nm}$ compared to untreated controls. $\Delta 340 \mathrm{~nm}$ reflects decrease of mannitol dehydrogenase activity, and $\Delta 260 \mathrm{~nm}$ reflects decrease of eDNA in biofilm. $a, p<0.01$, compared with amoxicillin; $b, p<0.01$, compared with the saponin; $c, p<0.01$, compared with erythromycin. Amo: amoxicillin; Sap: saponin; Ery: erythromycin

its anti-biofilm effect. It suggests that molecular docking can be used to predict the saponin effect on biofilm inhibition.

Saponins are detergent-like substances showing antibacterial potential, and the mechanism deserves discussion.
The critical micelle concentration of the camelliagenin is $0.5 \%$ [27], but its $\mathrm{MIC}_{90}$ and $\mathrm{IC}_{50}$ are far away from the concentration whereas it shows detergent activity, demonstrating that its antibacterial activity is not due to the surface property. It is reported that the effect of saponin is 

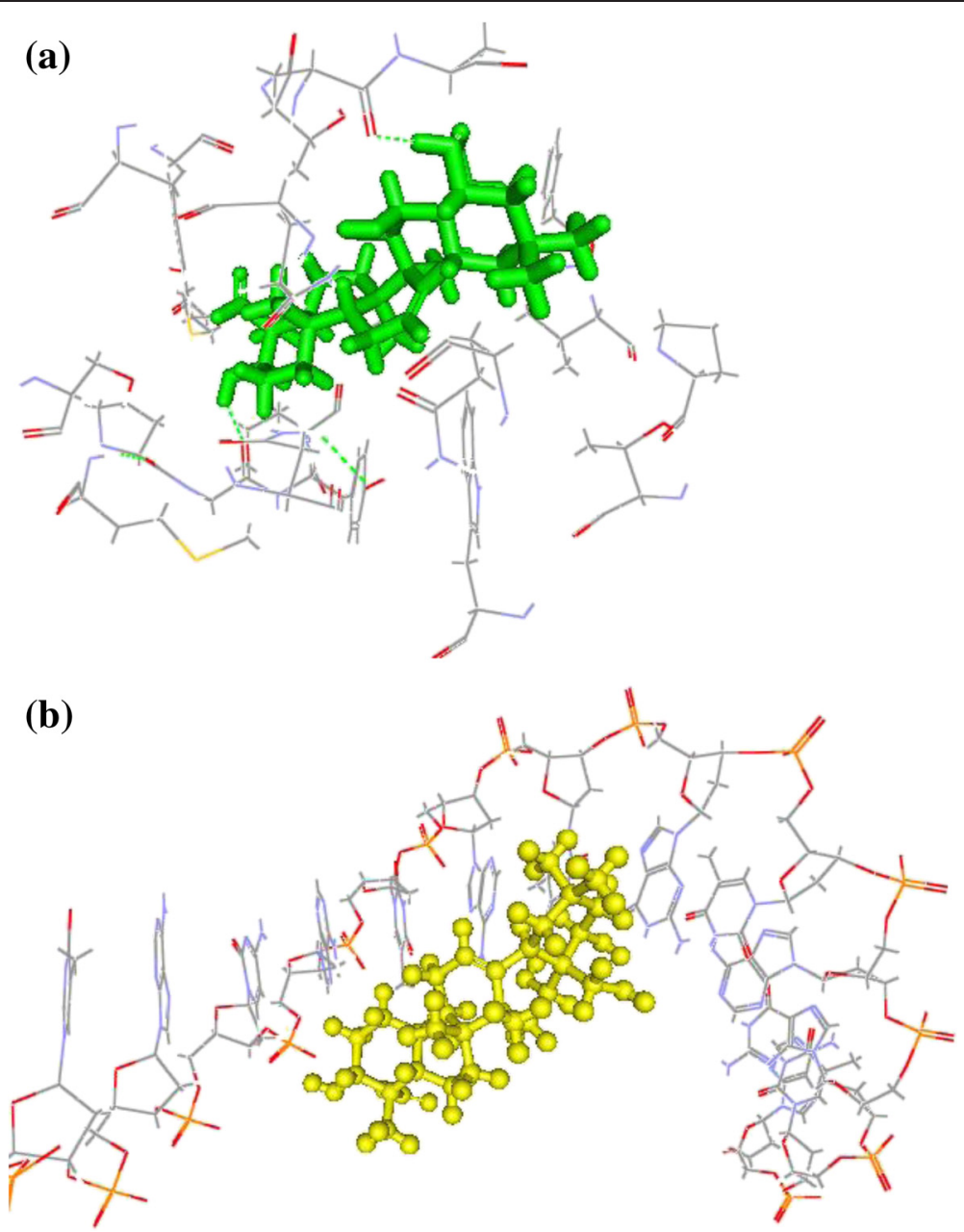

Fig. 6 Interaction of the saponin with mannitol dehydrogenase (a) and extracellular DNA (b)

associated with the changing of membrane permeability of Gram-negative cells in contrast to Gram-positive cells. Saponin might interact with Gram-negative cells components, like lipid A and thereby increase the permeability of bacterial cell wall [28]. Because the camelliagenin can reduce mannitol dehydrogenase and eDNA in biofilm, we provide a new hypothesis that the camelliagenin interacts with key components in biofilm, and blocks their activities in biofilm formation. The interaction of the camelliagenin with mannitol dehydrogenase and eDNA contributes to its anti-biofilm activity.

\section{Conclusions}

The camelliagenin is isolated from the defatted seeds of C. oleifera by ultrasonic assisted acid-base alternative technique. This is cost effective for industrialization because no organic solvent and expensive equipment are applied in the process. It is identified as camelliagenin and has significant antibacterial activities on E. coli and $S$. aureus in vitro and in vivo. It suggests that the camelliagenin is hopeful candidate for prevention of antibiotic resistance. The effects of the camelliagenin include its inhibition on bacterial biofilm formation, which is related to $\mathrm{MDH}$ and eDNA in the biofilm. The camelliagenin can spontaneously bind to and interact with $\mathrm{MDH}$ and eDNA. That could be the mechanism of the camelliagenin action on the two bacteria.

\section{Methods}

\section{Drugs and bacteria}

The defatted seeds of Camellia oleifera Abel were collected from oil manufacturing company (Meizhou, China). Escherichia coli was collected from fecal samples of chicks with generalized colibacillosis in Guangdong Chicken Farm, and identified as amoxicillin-resistant E. coli using the reported method [29]. Staphylococcus aureus was collected from nasal swab species of chicks with staphylocosis in Guangxi Chicken Farm, and identified as erythromycinresistant $S$. aureus by the method in the reference [30]. The fecal and nasal samples from the chickens were taken 
after we obtained consent from the farm owners. E. coli control strain ATCC25922 and S. aureus control strain ATCC25923 were purchased from Guangdong Microbial Institute (Guangzhou, China). Reagents for biofilm assay were $\mathrm{NH}$ broth, crystal violet, amoxicillin and erythromycin purchased from Shanghai Hualan Biochemical Company (Shanghai, China). Chemical reference substance camelliagenin was bought from Shanghai Chemicals Company (Shanghai, China). Other reagents were purchased from Guangzhou Reagent Company (Guangzhou, China).

\section{Animals}

The experiments were carried out on ten-day-old male Roman chicks. The chicks were housed under conditions of $24 \pm 2{ }^{\circ} \mathrm{C}, 50 \pm 10 \%$ humidity with a $12 \mathrm{~h}$ light/ dark cycle for 1 week adaptation. Food and water were accessible ad libitum. The experiments have been performed in accordance with the Chinese guidelines for the use of laboratory animals, and received approval from the animal experimentation ethic committee of South China University of Technology. All efforts were made to minimize animal suffering and to reduce the number of animals used. All sections of this report adheres to the ARRIVE guidelines for reporting animal research. A completed ARRIVE guidelines checklist is included in Checklist.

\section{Procedure of the isolation}

$1 \mathrm{~kg}$ of the defatted seeds of $C$. oleifera were crushed to pass through 20 mesh sieve, submerged in $2 \% \mathrm{HCl}$ aqueous solution (water $/$ seeds $=20 / 1 \mathrm{in} \mathrm{ml} / \mathrm{g}$ ) with ultrasonic at $300 \mathrm{~W}$ for $1 \mathrm{~h}$. In order to protect the compounds from heat, temperature was controlled below $60{ }^{\circ} \mathrm{C}$ with cooling water. The extract solution was stood for $5 \mathrm{~h}$. The precipitate was washed with $1000 \mathrm{ml}$ of $2 \%$ $\mathrm{NaOH}$ and $500 \mathrm{ml}$ of water, and dried in vacuum to get the saponin extract.

\section{Determination of purity by HPLC}

The analysis of saponin was run on HP 1100 HPLC (Agilent Company, USA) in the following operating conditions: column: Hypersil ODS $(250 \times 4.6 \mathrm{~mm}$, $5 \mu \mathrm{m})$; flow phase: methanol/water $(80 / 20)$; injection volume: $10 \mu$ l; flow rate: $1 \mathrm{ml} / \mathrm{min}$; temperature: $25^{\circ} \mathrm{C}$; wavelength: $209 \mathrm{~nm}$ [31].

\section{Structure determination}

$1 \mathrm{~g}$ of saponin extract was dissolved in $5 \mathrm{ml}$ of $80 \%$ methanol, and purified by silica gel chromatograph with elution by chloroform/methanol (8/2). The peaks were collected and dried in vacuum, and $0.5 \mathrm{~g}$ saponin was obtained for structural analysis.

UV spectra analysis was carried out on UV-3010 Ultra violet spectrometer (Hitachi Company, Japan) scanning from 200 to $600 \mathrm{~nm}$. IR spectra were measured on Nicolet 380 FI-IR spectrograph (Nicolet Apparatus Company, USA) with $\mathrm{KBr}$ tablets from 4000 to $400 \mathrm{~cm}^{-1}$ with resolution $2 \mathrm{~cm}^{-1}$. Mass spectra were recorded on Bruker Esquire Hct Plus Mass spectrometer with ESI (Bruker Company, Germany) in $\mathrm{m} / \mathrm{z}$ of cation model scanning from 150 to 1200 for $60 \mathrm{~min}$. NMR spectra were determined on $400 \mathrm{MHz}$ AM NMR (Bruker Company, Switzerland) in DMSO- $\mathrm{d}_{6}$ operating at $101 \mathrm{MHz}$ for ${ }^{13} \mathrm{C}$ NMR and $400 \mathrm{MHz}$ for ${ }^{1} \mathrm{H}$ NMR.

\section{Antibacterial activity}

The antibacterial activity of the saponin against $E$. coli and $S$. aureus was examined using the microbroth dilution method according to the CLSI standard [32]. Thirty-five strains of E. coli and 30 strains of S. aureus were isolated using the method reported [33, 34], they were respectively inoculated in broth medium, which was cultured for $24 \mathrm{~h}$ at $37^{\circ} \mathrm{C}$, and diluted to $10^{5} \mathrm{CFU} / \mathrm{ml}$. Serial dilutions were prepared from $500 \mu \mathrm{g} / \mathrm{ml}$ of the saponin using DMSO to make 500, 250, 125, 62.5, 31.25, and $15.625 \mu \mathrm{g} / \mathrm{ml}$. The wells were inoculated with $0.1 \mathrm{ml}$ aliquot of test bacteria $\left(10^{5} \mathrm{CFU} / \mathrm{ml}\right)$ having serial dilutions of the saponin $(50 \mu \mathrm{l}$, each). The micro plate was incubated at $37{ }^{\circ} \mathrm{C} \pm 1{ }^{\circ} \mathrm{C}$ for $24 \mathrm{~h}$. Dilution of the saponin to respective test organism showing no visible growth was considered as MIC. The minimum inhibitory concentration on $90 \%$ bacterial strains was calculated as $\mathrm{MIC}_{90}$.

\section{Bacterial biofilm experiment}

Bacterial biofilm experiments were carried out according to the reference [35]. The diluted bacteria $\left(10^{5} \mathrm{CFU} / \mathrm{ml}\right)$ of $E$. coli and $S$. aureus were divided into the saponin groups, negative control (no drug), antibiotic groups (amoxicillin and erythromycin) and groups of the saponin plus antibiotics $(1: 1,5: 1,10: 1)$ with 5 repetition wells for each. The extracts were dissolved with water to $500 \mu \mathrm{g} / \mathrm{ml} .50 \mu \mathrm{l}$ of drug solution and $450 \mu \mathrm{l}$ of diluted bacteria (final drug concentration $50 \mu \mathrm{g} / \mathrm{ml}$ ) were mixed in one well of 24 well plates, cultured for $24 \mathrm{~h}$, and then absorbance in $490 \mathrm{~nm}\left(\mathrm{OD}_{490}\right)$ was measured with water as blank to calculate the bacterial growth inhibition rate. The medium in the cell was carefully removed and washed 3 times with $1 \mathrm{ml}$ of distilled water, and $1 \%$ crystal violet solution $(500 \mu \mathrm{l})$ was added to dye the biofilm. $30 \mathrm{~min}$ later, the solution was aspirated, and $500 \mu \mathrm{l}$ of ethanol was added to extract crystal violet from the biofilm. The absorbance in $560 \mathrm{~nm}\left(\mathrm{OD}_{560}\right)$ was determined with ethanol as blank to calculate the biofilm inhibition rate.

$$
\begin{aligned}
& \text { Bacterial growth inhibtion rate (\%) } \\
& =\frac{\left(\text { Negative } \mathrm{OD}_{490}-\mathrm{Drug}_{\mathrm{OD}} \mathrm{D}_{40}\right)}{\text { Negative } \mathrm{OD}_{490}} \times 100 \%
\end{aligned}
$$


Biofilm inhibition rate (\%)

$$
=\frac{\left(\text { Negative } \mathrm{OD}_{560}-\mathrm{Drug}_{\mathrm{OD}} \mathrm{D}_{560}\right)}{\text { Negative } \mathrm{OD}_{560}} \times 100 \%
$$

Inhibitory concentrations $\left(\mathrm{IC}_{50}\right)$ of the drugs on $50 \%$ bacterial growth and biofilm formation were determined by dilution until the inhibition rate was $50 \%$. It is used as the index to evaluate the inhibitory effects on bacteria.

\section{Assay of mannitol dehydrogenase and extracellular DNA in biofilm}

The saponin extract and the antibiotics were diluted to final drug concentration in culture medium at 50, 25, $12.5,5,2.5,1 \mu \mathrm{g} / \mathrm{ml}$ for $48 \mathrm{~h}$ bacteria culture. After removing the medium, the biofilm was homogenized in $500 \mu \mathrm{l}$ of $50 \mathrm{mmol} / \mathrm{l}$ phosphate buffer (pH 5.5), $10 \mu \mathrm{l}$ of the supernatant was taken for enzyme activity assay, and the rest was used for extracellular DNA determination.

Mannitol dehydrogenase (MDH) activity was determined according to a modified method [36]. Briefly, MDH was measured by the decrement of NADH, which was monitored by the absorbance at $340 \mathrm{~nm}$. The reaction mixture contained $50 \mu \mathrm{l}$ of $200 \mathrm{mM}$ sodium phosphate buffer (pH 5.5), $50 \mu \mathrm{l}$ of $2 \mathrm{mM} \mathrm{NADH}, 50 \mu \mathrm{l}$ of water and $10 \mu \mathrm{l}$ of the biofilm extract. The mixture was maintained at $32{ }^{\circ} \mathrm{C}$ for $2 \mathrm{~min}$, and the reaction was started by adding $40 \mu \mathrm{l}$ of $1 \mathrm{M}$ fructose and lasted for $5 \mathrm{~min}$. The absorbance at $340 \mathrm{~nm}$ was detected by UV-3010 spectrometer (Hitachi Company, Japan).

Extracellular DNA (eDNA) was measured in the following protocol [37]. The biofilm extract was mixed with $10 \mathrm{U} / \mathrm{ml}$ cellulase at $37{ }^{\circ} \mathrm{C}$ for $1 \mathrm{~h}$, followed by treatment with $10 \mathrm{U} / \mathrm{ml}$ proteinase $\mathrm{K}$ for another $1 \mathrm{~h}$. Treated samples were centrifuged at $10,000 \mathrm{~g}$ for $10 \mathrm{~min}$. The supernatant was collected and the absorbance was detected at $260 \mathrm{~nm}$ by UV spectrometer to deduce eDNA content in biofilm.

\section{Antibacterial test in vivo}

The antibacterial tests were performed as the reported with some modification [38]. Two tests including E. coli and $S$. aureus were carried out separately. For one test, the chicks were randomly divided into 9 groups with 30 chicks in each group, including normal group, negative group, antibiotic group, the saponin extract and the saponin extract plus antibiotic groups in high, middle and low dose. The groups of chicks except normal group were injected intraperitoneally with $0.2 \mathrm{ml}$ of $1 \times 10^{8} \mathrm{CFU} / \mathrm{ml}$ bacterial suspension, $10 \mathrm{~h}$ later they were administered with $1 \mathrm{~kg}$ of feed containing $50 \mathrm{mg}$ amoxicillin or erythromycin in antibiotic group, $50 \mathrm{mg}, 250 \mathrm{mg}$ and $500 \mathrm{mg}$ in low, middle and high dose of the saponin extract respectively for consecutive $3 \mathrm{~d}$. The doses were based on regular use of antibiotics and safety of the saponin [39]. The chicks were weighed, monitored for $14 \mathrm{~d}$, and evaluated by relief of symptoms of anorexia, lassitude, diarrhea, etc. [40]. The chicks were euthanized on the fifteenth day, thymus and spleen were removed and weighed to calculate immune organ index (organ weight / body weight). Chick liver was plated onto Tryptose Soya Agar (TSA) plates for bacterial colony count, and the bacterial density was expressed as the number of CFU per liver.

\section{Simulation of molecular interaction}

Molecular docking was simulated by Discovery Studio V2.5 software (Accelry Inc., CA, USA) in the following procedure [41]. Structural data of mannitol dehydrogenase and eDNA were downloaded from Brookhaven Library. The missing amino acids and hydrogens were supplemented, and excessive protein conformation was removed. Mannitol dehydrogenase and eDNA were separately defined as the receptor, and then binding sites and coordinates were defined. A new plot window was open to draw structure of the extracts, optimize $3 \mathrm{D}$ geometric structures, and apply CHARMm force field to ensure correct bond length, bond angle in a state of energy stability. CDOCKER Protocol was run to obtain binding parameters, which are used to evaluate the interaction. CDOCKER energy and CDOCKER interaction energy are two important parameters, and their absolute values are in according with the affinity and action force between the receptor and ligand.

\section{Statistical analysis}

Data was presented as mean \pm standard deviation $(\bar{x} \pm s)$. SPSS 11.0 software (SPSS Inc., USA) was used to analyze the data of animal tests in groups by one-way ANOVA and Dunnett's test.

\section{Competing interests}

The authors declare that they have no competing interests.

\section{Authors' contributions}

YY designed the study and wrote and critically revised the manuscript. QY, $F F$, and $Y L$ performed the experiments, analyzed the data, and drafted the manuscript. All authors read and approved the final manuscript.

\section{Acknowledgements}

The authors thank the staff in the laboratory centre of South China University of Technology for analyzing spectroscopic data. The financial support for this work from the NSFC (No. 81173646) and Guangzhou Scientific Plan Project (No. 201510010065) are also gratefully acknowledged.

Received: 4 December 2014 Accepted: 4 August 2015

Published online: 18 August 2015

\section{References}

1. Jing MJ, Jing XJ, Wang YJ. Investigation on epidemiology of chicken colibacillosis. Chin Livest Poult Breed. 2011;7:151-2.

2. Tian W, Zhao JJ, Deng YT, Yao QF, Chen XJ, Liu JH. Prevalence of oqxAB multidrug efflux pump in Escherichia coli isolated from animals. Chin Anim Husb Vet Med. 2011;38:156-9.

3. Zhang T, Wang CG, LV JC, Wang RS, Zhong XH. Survey on tetracycline resistance and antimicrobial-resistant genotype of avian Escherichia coli in North China. Poult Sci. 2012;91:2774-7. 
4. Dai FW, Ke XF, Zhou SS, Song XM, Sa XY. The epidemiology of methicillin-resistant staphylococcus aureus (MRSA) in animals. Chin J Compar Med. 2010;20:81-5

5. Li WL, Huang FH, Wang LB. Review on processing and comprehensive utilization of oil tea camellia seed. China Oils Fats. 2011;36:55-7.

6. Li XZ, Zhang S, Li WS. a-Glucosidase inhibitory activity of Camellia cake polysaccharides in vitro. J Hunan Univ (Nat Sci). 2012;39:71-3.

7. Luo YM, Li B, Xie YH. Study on the chemical constituents of Camellia oleifera Abel. Chin Trad Herbal Drugs. 2003;34:117-8.

8. Chen YF, Yang $\mathrm{CH}$, Chang MS, Ciou YP, Huang YC. Foam properties and detergent abilities of the saponins from Camellia oleifera. Int J Mol Sci. 2010;11:4417-25.

9. Du LC, Wu BL, Chen JM. Flavonoid triglycosides from the seeds of Camellia oleifera Abel. Chin Chem Lett. 2008;19:1315-8.

10. Wei $X L$, Mao FF, Cai X, Wang Y. Composition and bioactivity of polysaccharides from tea seeds obtained by water extraction. Int J Biol Macromol. 2011:49:587-90.

11. Ye $Y$, Xing HT, Chen XL. Anti-inflammatory and analgesic activities of the hydrolyzed sasanquasaponins from the defatted seeds of Camellia oleifera. Arch Pharm Res. 2013;36:941-51.

12. Blackledge MS, Worthington RJ, Melander C. Biologically inspired strategies for combating bacterial biofilms. Curr Opin Pharmacol. 2013;13:699-706.

13. Gao DF, Xu M, Zhao P, Zhang XY, Wang YF, Yang CR, et al. Kaempfero acetylated glycosides from the seed cake of Camellia oleifera. Food Chem. 2011;124:432-6.

14. Chen JH, Liau BC, Jong TT, Chang CM. Extraction and purification of flavanone glycosides and kaempferol glycosides from defatted Camellia oleifera seeds by salting-out using hydrophilic isopropanol. Sep Purif Technol. 2009;67:31-7.

15. Ghafoor K, Choi YH, Jeon JY, Jo $\Perp H$. Optimization of ultrasound-assisted extraction of phenolic compounds, antioxidants, and anthocyanins from grape (Vitis vinifera) seeds. J Agri Food Chem. 2009;57:4988-94.

16. Toshiyuki M, Junko N, Hisashi M, Masayuki Y. Bioactive saponins and glycosides. XV.1) saponin constituents with gastroprotective effect from the seeds of tea plant, Camellia sinensis L. var. assamica, cultivated in Sri Lanka: structures of assamsaponins A, B, C, D, and E. Chem Pharm Bull. 1999:47:1759-64

17. Haussler S, Parsek MR. Biofilms 2009: new perspectives at the heart of surface-associated microbial communities. J Bacteriol. 2010;192:2941-9.

18. Jensen $P \varnothing$, Bjarnsholt T, Phipps R, Rasmussen TB, Calum H, Christoffersen L, et al. Rapid necrotic killing of poly-morphonuelear leukocytes is caused by quorum -sensing-controlled production of rhamnolipid by Escherichia Coli. J Microbiol. 2007;53:1329-38.

19. Orgad O, Oren Y, Walker SL, Herzberg M. The role of alginate in Escherichia Coli EPS adherence, viscoelastic properties and cell attachment. Biofouling. 2011;27:787-98.

20. Banerjee PC, Vanags RI, Chakrabarty AM. Alginic acid synthesis in Escherichia Coli mutants defective in carbohydrate metabolism. J Bacteriol. 1983:155:238-45

21. Martin CA, Hoven AD, Cook AM. Therapeutic frontiers: preventing and treating infectious diseases by inhibiting bacterial quorum sensing. Eur J Clin Microbiol Infect Dis. 2008;27:635-42.

22. Nur A, Hirota K, Yumoto H. Effects of extracellular DNA and DNA-binding protein on the development of a Streptococcus intermedius biofilm. J Applied Microbiol. 2013;115:260-70.

23. Mulcahy $\mathrm{H}$, Charron ML, Lewenza S. Extracellular DNA chelates cations and induces antimicrobial resistance in Escherichia Coli biofilms. PLoS Pathog. 2008:4:1213-8

24. Ou YZ, Zhu YL, Chen JM. The mechanism of JSfnp Zococc epidemics AtIE protein mediating primary attachment of biofilm formation. Fudan Univ J Med Sci. 2006;33:569-73.

25. Donlan RM, Costerton JW. Biofilms: survival mechanisms of clinically relevant microorganisms. Clin Microbiol Rev. 2002;15:167-93.

26. Duan AX, Chen J, Liu HD. Applications and developments of molecular docking method. J Anal Sci. 2009;25:473-7.

27. Chen YF, Yang CH, Chang MS, Ciou YP, Huang YC. Foam properties and detergent abilities of the saponins from Camellia oleifera. Int J Mol Sci. 2010;11:4417-25
28. Arabski M, Wasik S, Dworecki K, Kaca W. Laser interferometric and cultivation methods for measurement of colistin/ampicilin and saponin interactions with smooth and rough of Proteus mirabilis lipopolysaccharides and cells. J Microbiol Methods. 2009;77:178-83.

29. El-Rami FE, Sleiman FT, Abdelnoor AM. Identification and antibacterial resistance of bacteria isolated from poultry. Pol J Microbiol. 2012;61:323-6.

30. Wang GQ, Xing ZH, Wei YZ. Antimicrobial resistance of Staphylococcus aureus isolated from chicken. J Agri Sci. 2011;32:43-9.

31. Zhao JJ, Du XF. Sasanquasaponin reference substance preparation and quantitative analysis by HPLC. China Oil Fats. 2009;34:68-7.

32. Umer S, Tekewe A, Kebede N. Antidiarrhoeal and antimicrobial activity of Calpurnia aurea leaf extract. BMC Complem Altern Med. 2013;13:21-5.

33. Zhang JL. Isolation and identification of drug-resistant Escherichia coli strains from chickens. Agri Sci Tech. 2012;13:1699-701.

34. Qiu M, Hao Z, Zhang WJ, Shen W, Wu B, Li YH, et al. Isolation and identification of Staphylococcus aureus from animals and drug resistance analysis. Chin Agri Sci Bull. 2011:27:356-9.

35. Robert WH, Justin JR. Inhibition of Escherichia Coli biofilm formation with bromoageliferin analogues. J Am Chem Soc. 2007;129:6966-7.

36. Ortiz ME, Fornaguera MJ, Raya RR, Mozzi F. Lactobacillus reuteri CRL 1101 highly produces mannitol from sugarcane molasses as carbon source. Appl Microbiol Biotechnol. 2012:95:991-9.

37. Wu J, Xi C. Evaluation of different methods for extracting extracellular DNA from the biofilm matrix. Appl Environ Microb. 2009:75:5390-5.

38. Haritova A, Urumova V, Lutckanov M, Petrov V, Lashev L. Pharmacokinetic-pharmacodynamic indices of enrofloxacin in Escherichia coli O78/H12 infected chicks. Food Chem Toxicol. 2011:49:1530-6.

39. Hu SH, Wei J, Yan XW, Li QM. The poisonous study of Sasanqua saponin-the acute poisonous and accumulated poisonous of Sasanqua saponin to SD mouse through its mouth and skin. China Oils Fats. 1998;23:47-8.

40. Liang Y. Prevention and treatment on colibacillosis \& pullorosis with extracts from Scutellaria baicalensis Georgi in chickens. J Trad Chin Vet Med. 2007;2:20-2

41. Uthaman G, Mannu J, Durai S. Molecular docking studies of dithionitrobenzoic acid and its related compounds to protein disulfide isomerase: computational screening of inhibitors to HIV-1 entry. BMC Bioinf. 2008;9:S14-16

\section{Submit your next manuscript to BioMed Central and take full advantage of:}

- Convenient online submission

- Thorough peer review

- No space constraints or color figure charges

- Immediate publication on acceptance

- Inclusion in PubMed, CAS, Scopus and Google Scholar

- Research which is freely available for redistribution

Submit your manuscript at www.biomedcentral.com/submit
C Biomed Central 